\title{
Studi Butir Soal IPA Pokok Bahasan Biologi di SMP Tentang Keterampilan Menjelaskan Fenomena Secara Ilmiah
}

\section{The Study of Instrument Assessment in Biology Subjects about Explaining Phenomena Scientifically Skills in Junior High School}

\author{
Atini Ilannur, Ana Ratna Wulan \& Sariwulan Diana \\ Universitas Pendidikan Indonesia, Bandung, Jawa Barat, Indonesia \\ atiniilannur@upi.edu
}

Naskah diterima tanggal 10/05/2020, direvisi akhir tanggal 22/07/2020, disetujui tanggal 30/08/2020

\begin{abstract}
Abstrak
Studi ini bertujuan untuk menelaah butir soal IPA pokok bahasan Biologi di Sekolah Menengah Pertama (SMP) Kota Bandung mengenai keterampilan menjelaskan fenomena secara ilmiah. Penelitian ini memakai metode studi deskriptif melalui pengumpulan soal Penilaian Tengah Semester (PTS) dan Penilaian Akhir Semeseter (PAS) dari enam sekolah di Kota Bandung yang dipilih secara stratified random sampling dengan kategori baik, cukup dan kurang. Sebanyak 267 soal IPA pokok bahasan Biologi dari enam SMP di Kota Bandung terkumpul. Soal ditelaah menggunakan indikator keterampilan menjelaskan fenomena secara ilmiah yang terdapat pada framework PISA 2018. Hasil telaah menunjukkan bahwa hanya sebagian kecil (1,86\%) butir soal dari enam SMP kota Bandung yang memuat keterampilan menjelaskan fenomena secara ilmiah. Hasil penelitian menunjukkan butir soal yang digunakan cenderung langsung menanyakan penguasaan konsep siswa dan tidak menyajikan data/informasi yang perlu diselidiki siswa pada stem soal. Sebagian besar soal yang disajikan berupa hapalan materi sehingga kurang menuntut siswa untuk berpikir tingkat tinggi dan bernalar.
\end{abstract}

Kata kunci: Asesmen, IPA-biologi, Fenomena Ilmiah

\begin{abstract}
This study examines the subject Sciences in Biology of Junior High Schools in Bandung about explaining phenomena scientifically skills. To achieve this goal, an descriptive study through the collection of items Mid Semester and Final Semeseter Assessment from six schools in the city of Bandung were selected by stratified random sampling with good, sufficient and less category. A total of 267 science questions on Biology were collected. The items analyzed using the skills description explain the scientific phenomena contained in the 2018 PISA framework. The result of analysis showed that only in a small part (1.86\%) questions from six schools in Bandung City that fill ezamined the skill in explaining the phenomena scienctifically. The result showed the question that used was tended directly asked about students' mastery consepts and didnt present the data/information that students needed to investigate in the question stem. Most of the question that presented in a form of memorizing the matrial, so that was making students can't think with high standard and reasonable.
\end{abstract}

Keywords: Assessment, Phenomena Scientifically, Science-Biology 


\section{PENDAHULUAN}

Abadke-21 ditandai sebagaiabadketerbukaan atau era globalisasi, yang artinya kehidupan manusia pada abad ke- 21 mengalami perubahan yang fundamental dari peradaban sebelumnya (Wijaya et al., 2016). Tantangan abad ke- 21 yaitu menyiapkan sumber daya manusia (SDM) yang dapat bersaing di era globalisasi yang menuntut manusia untuk mengembangkan keterampilan yang dibutuhkan untuk hidup pada abad ke- 21 (Yamamoto, 2009). Partnership for $21^{\text {st }}$ Century Skills mengemukakan kompetensi abad ke- 21 kedalam enam elemen kunci, yaitu memiliki subyek inti, kompetensi belajar, alat, konteks, konten dan asesmen baru yang valid untuk digunakan sebagai alat ukur kompetensi abad ke- 21 (Salpeter, 2013). Kompetensi belajar merupakan elemen penting, yang menuntut siswa untuk menggunakan pengetahuan dan kompetensi mereka dalam berpikir kritis, menerapkan pengetahuan pada situasi baru, menganalisis informasi, berkomunikasi, berkolaborasi, memecahkan masalah, dan mengambil keputusan (Salpeter, 2013).

Peran mata pelajaran IPA- Biologi dalam penguasaan kompetensi abad ke-21 sangat strategis, terutama dalam menyiapkan siswa yang kritis, kreatif, mampu memecahkan masalah, dan mengambil keputusan secara tepat. Kompetensi tersebut dapat diwujudkan melalui sistem pendidikan yang mengadaptasi kompetensi abad ke-21 dalam setiap aspeknya. Misalkan dalam perencanaan, pelaksanaan, asesmen dan evaluasi. Asesmen dipandang sebagai penilaian proses, kemajuan, dan hasil belajar siswa (outcomes) (Stiggins, 1994). Asesmen juga diartikan sebagai "The process of collecting data which shows the development of learning" (Kumano, 2001). Zachos (2004) menyatakan bahwa asesmen adalah proses mendapatkan bukti untuk mendukung kesimpulan tentang pencapaian tujuan pembelajaran siswa. Asesmen atau penilaian merupakan elemen kunci dalam pembaruan kurikulum dan perubahan pada praktik-praktik kurikulum (Australian Learning \& Teaching Council, n.d.). Beberapa negara yang mengimplementasikan data hasil asesmen sebagai perubahan kurikulum adalah negara Australia (Schleicher, 2017), Jerman (Waldow, 2009), dan Indonesia (Pratiwi, 2019a) yang mengadaptasi data hasil asesmen Programme for International Student Assessment (PISA) sebagai landasan perubahan kurikulum pendidikan tingkat nasional. PISA merupakan salah satu program penilaian yang mengukur ketercapaian literasi sains siswa (OECD, 2018). Capaian literasi sains yang diukur melalui PISA diperuntukkan pada siswa usia 15 tahun (OECD, 2018) atau setara dengan siswa yang duduk pada jenjang kelas tiga Sekolah Menengah Pertama (SMP) (Kemendikbud, 2018).

Data hasil asesmen PISA dapat dijadikan wawasan untuk praktik kebijakan dalam dunia pendidikan dan memberikan gambaran hasil capaian siswa terhadap sistem pendidikan yang berlangsung. Data hasil penilaian PISA dapat dijadikan rujukan dalam mengevaluasi sistem pendidikan agar tujuan pembangunan manusia dapat ditingkatkan (OECD, 2018). Beragam hasil analisa dari PISA dapat digunakan untuk mengambil kebijakan pendidikan di Indonesia, baik di tingkat pusat maupun daerah, sebagai upaya perbaikan sumber daya manusia di abad 21 (Suprayitno, 2019), salah satunya dapat memberikan masukkan terhadap perbaikan sistem asesmen dalam dunia pendidikan. Kemendikbud (2019) mengungkapkan bahwa pembenahan sistem asesmen dapat digunakan untuk mengatasi rendahnya kompetensi siswa dan hasil penilaian pendidikan Indonesia, asesmen yang dikembangkan harus berfokus pada tuntutan kompetensi abad ke- 21 .

Kompetensi literasi sains abad ke21 yang ditawarkan PISA, salah satunya tentang kompetensi menjelaskan fenomena secara ilmiah (OECD, 2018). Kompetensi menjelaskan fenomena secara ilmiah merupakan inti dari sebuah pengetahuan (Goh, 2016) yang sebaiknya dibekalkan kepada siswa, dan merupakan kompetensi yang sangat dibutuhkan untuk menjadi bekal dalam menghadapi tantangan abad ke- 21 (Sandoval \& Millwood, 2005; Wang, 2014). Terdapat lima indikator yang terdapat pada keterampilan 
menjelaskan fenomena secara ilmiah, yaitu menerapkan pengetahuan ilmiah dengan tepat, menggunakan gambaran serta model dengan jelas, menyusun dan memberikan prediksi dengan tepat, mengajukan hipotesis penjelasan dan menjelaskan implikasi potensial dari pengetahuan ilmiah untuk masyarakat (OECD, 2018). Kompetensi menjelaskan fenomena secara ilmiah menuntut siswa untuk memahami pengetahuan konten, juga harus mengetahui dari mana pengetahuan itu diperoleh, tingkat kepercayaan pengetahuan dan prosedur ilmiah yang mendasari perolehan pengetahuan tersebut (OECD, 2017).

Kompetensi menjelaskan fenomena secara ilmiah, menuntut siswa untuk memiliki kemampuan berpikir tingkat tinggi, analitis dan kritis dalam membentuk sebuah penjelasan berdasarkan penyelidikan dan pemahaman yang dibentuk sendiri (OECD, 2018). Selain itu, kemampuan menjelaskan secara ilmiah juga melatih kemampuan penalaran siswa (Lawson et al., 2000, 2007; Supeno et al., 2017). Penalaran sangat dibutuhkan untuk menguji sebuah pengetahuan yang bersifat kausal (Ates $\&$ Cataloglu, 2007). Maka dari itu kompetensi menjelaskan fenomena secara ilmiah sangat penting untuk dibekalkan dan dinilai agar siswa memiliki kemampuan penalaran, kemampuan pemecahan masalah, berpikir analitis, kritis, kemampuan HOTS, dan mampu mengambil keputusan secara tepat (OECD, 2017).

Disisi lain ditemukan bahwa sejak tahun 2000 sampai tahun 2018 menempatkan Indonesia sebagai salah satu negara dengan peringkat literasi sains yang rendah (Narut \& Supardi, 2019) berdasarkan hasil capaian PISA. Literasi sains (scientific literacy) merupakan pengetahuan dan pemahaman dari konsepkonsepdanproses-prosesilmiahyangdiperlukan untuk pengambilan keputusan. Literasi sains juga melibatkan kemampuan-kemampuan spesifik. Seorang warganegara yang "literate" seyogianya mampu mengevaluasi kualitas informasi ilmiah berdasarkan sumbernya, dan juga metode-metode yang digunakan untuk menghasilkannya (Rustaman, 2017). Penelitian tentangkemampuanliterasisainstelahdilakukan pada siswa SMP se-kabupaten Sumedang, yang menunjukkan bahwa kemampuan literasi sains siswa SMP yang dijaring dengan menggunakan instrumen Scientific Literacy Assessment (SLA), masih kurang sekali (Rachmatullah, 2015). Sariwulan et al., (2015) juga mengungkapkan bahwa kemampuan literasi sains pada aspek kemampuan berpikir dan bekerja secara ilmiah rendah atau sebesar $37,0 \%$. Hal tersebut didukung oleh hasil penelitian Imani dan Purwanto (2016) yang dilakukan di SMP dengan instrumen soal PISA diperoleh hasil persentase kompetensi literasi sains pada keterampilan menjelaskan fenomena secara ilmiah siswa sebesar 48,20\% dengan kategori rendah. Hasil riset (Ayuningtyas, 2016; Elvadola, 2016; Hartika, 2016; Novika, 2016) pada kompetensi menjelaskan fenomena ilmiah yang dilakukan di SMP pada pokok bahasan Biologi, pencemaran lingkungan (ozon, efek rumah kaca, resiko kesehatan dan hujan asam), biodiversitas, sistem gerak, sistem pencernaan, sistem koordinasi, dan sistem pernapasan, diperoleh rata- rata skor berturut turut sebesar 19,$6 ; 23,5 ; 28,5$; dan 29,8 dengan kategori sangat rendah. Hal senada juga ditemukan pada penelitian Shopia (2013) yang dilakukan di SMA, pada pokok bahasan Biologi yang terdapat pada soal-soal PISA, diperoleh persentase pada kompetensi menjelaskan fenomena secara ilmiah sebesar $34,09 \%$ dengan kategori rendah.

Rendahnya literasi sains siswa salah satunya, kompetensi menjelaskan fenomena secara ilmiah, dapat disebabkan beberapa hal. Firman (2007) mengungkapkan bahwa, penyebab rendahnya pencapaian literasi sains siswa Indonesia dikarenakan kurangnya pembelajaran yang melibatkan proses sains, seperti memfomulasikan pertanyaan ilmiah dalam penyelidikan, menggunakan pengetahuan yang dimiliki untuk menjelaskan fenomena alam serta menarik kesimpulan beradasarkan fakta yang diperoleh dari penyelidikan. Selain itu ditemukan bahwa butir soal penilaian yang disajikan guru IPA untuk Penilaian Tengah Semester (PTS) mengenai soal Higher Order Thinking Skills (HOTS) masih tergolong rendah yaitu sebesar $(1,1 \%)$, padahal soal HOTS sangat diperlukan untuk mencapai tuntutan kompetensi abad ke- 21 (Pratiwi, 2019b). Tiararahmadani (2018) mengemukakan bahwa soal penilaian 
yang disajikan guru untuk Ulangan Harian (UH) yang menuntut siswa untuk berpikir tingkat tinggi masih tergolong kategori sangat kurang baik (6,7\%). Begitupula hasil penelitian Herlant \& Nopithalia (2005) pada soal biologi yang digunakan oleh guru dalam Penilaian Akhir Semester (PAS), menunjukkan 99\% tipe soal Lower Order Thinking Skills (LOTS). Hal senada juga ditemukkan pada hasil penelitian Anggraini (2014) yang mengungkapkan bahwa guru dalam proses pembelajarannya tidak menghadirkan hal yang dapat memacu siswa untuk berpikir tingkat tinggi seperti menyediakan teks pengantar dalam penilaian dan pembelajaran, media gambar ataupun skenario sebuah kasus untuk dipecahkan atau diselesaikan oleh siswa.

Berdasarkan studi literatur, belum banyak ditemukan hasil studi terhadap butir soal yang digunakan guru/sekolah tentang keterampilan menjelaskan fenomena secara ilmiah yang merupakan bagian dari literasi sains PISA 2018. Penelitian tentang butir soal tes tertulis dilakukan hanya pada menganalisis konten (Damayanti et al., 2016) kualitas butir soal tes tertulis (Amrianto, 2017; Ariyana, 2011; Johari, 2018; Samudar, 2019), dan kemampuan tingkat berpikir siswa (Ariyana, 2011; Septiana, 2016). Dilain pihak asesmen pembelajaran salah satunya tes tertulis dalam bentuk butir soal penilaian diharapkan menuntut aspekaspek literasi sains siswa, dengan tidak hanya bermuatan konsep saja (Sariwulan et al., 2015). Berdasarkan pemaparan di atas, diperlukan studi butir soal IPA pokok bahasan biologi di SMP tentang keterampilan menjelaskan fenomena secara ilmiah.

\section{METODE PENELITIAN}

Studi ini bertujuan untuk menelaah butir soal IPA pokok bahasan Biologi di Sekolah Menengah Pertama (SMP) Kota Bandungmengenaiketerampilanmenjelaskan fenomena secara ilmiah. Penelitian ini memakai metode studi deskriptif melalui pengumpulan soal Penilaian Tengah Semester (PTS) dan Penilaian Akhir Semeseter (PAS). Populasi pada penelitian ini adalah keterampilan menjelaskan fenomena secara ilmiah matapelajaran IPA-Biologi pada butir soal tes tertulis di Sekolah Menengah Pertama (SMP) Kota Bandung. Data dikumpulkan dari butir soal Penilaian Tengah Semester (PTS) dan Penilaian Akhir Semester (PAS) pada mata pelajaran IPA- Biologi yang digunakan sebagai asemen tes tertulis yang digunakan di SMP Kota Bandung. Sampel penelitian ditentukan dengan teknik stratified random sampling.

Proses pengambilan sampel dilakukan melalui rata- rata nilai Ujian Nasional (UN) siswa SMP tahun ajaran 2018/2019 dengan kategori "baik", "cukup" dan "kurang" dengan perbandingan 2:2:2 yang mengacu pada aturan Wulan et al., (2019) menggunakan kategori rerata baik dengan nilai UN $70<$ nilai $\leq 85$; cukup dengan nilai $55<$ nilai $\leq 70$ dan kurang dengan nilai rerata $U N 0 \leq$ nilai $\leq 55$ yang mengacu pada aturan BSNP (2019). Data dikumpulkan dari soal PTS dan PAS pada soal IPA- Biologi di SMP dari enam SMP di Kota Bandung, yang terdiri dari dua sekolah swasta dengan kategori "baik", satu sekolah negeri dan satu sekolah swasta dengan kategori "cukup", serta satu sekolah negeri dan satu sekolah swasta dengan kategori "kurang". Berikut disajikan Tabel 1 merupakan SMP yang digunakan dalam penelitian, sebagai berikut:

Tabel 1. SMP yang digunakan dalam penelitian

\begin{tabular}{clccc}
\hline No. & \multicolumn{1}{c}{ Sekolah } & $\begin{array}{c}\text { Status } \\
\text { Sekolah }\end{array}$ & $\begin{array}{c}\text { Rerata } \\
\text { Nilai UN }\end{array}$ & \multirow{2}{*}{ Kategori } \\
\cline { 1 - 3 } 1. & SMP A Kota Bandung & Swasta & 74,21 & \multirow{2}{*}{ Baik } \\
\cline { 1 - 3 } 2. & SMP B Kota Bandung & Swasta & 73,16 & \\
\cline { 1 - 3 } 3. & SMP C Kota Bandung & Swasta & 65,18 & \multirow{2}{*}{ Cukup } \\
\cline { 1 - 3 } 4. & SMPN D Kota Bandung & Negeri & 56,49 & \multirow{2}{*}{ Kurang } \\
\cline { 1 - 3 } 5. & SMPN E Kota Bandung & Negeri & 54,96 & \\
\hline
\end{tabular}

Sumber: Puspendik, 2019. 
Butir soal kemudian ditelaah dengan menggunakan framework PISA 2018 pada keterampilan menjelaskan fenomena secara ilmiah dengan indikator keterampilan, yang disajikan pada Tabel 2 indikator keterampilan menjelaskan fenomena secara ilmiah sebagai berikut:

Tabel 2. Indikator keterampilan Menjelaskan Fenomena secara Ilmiah

\begin{tabular}{cl}
\hline No. & \multicolumn{1}{c}{ Indikator keterampilan } \\
\hline 1. & menerapkan pengetahuan ilmiah dengan tepat \\
\hline 2. & menggunakan gambaran serta model dengan jelas \\
\hline 3. & menyusun dan memberikan prediksi dengan tepat \\
\hline 4. & mengajukan hipotesis penjelasan \\
\hline 5. & $\begin{array}{l}\text { menjelaskan implikasi potensial dari pengetahuan } \\
\text { ilmiah untuk masyarakat }\end{array}$ \\
\hline
\end{tabular}

\section{HASIL DAN PEMBAHASAN}

\subsection{Hasil}

Butir soal PTS dan PAS dianalisis berdasarkan kesesuaian dengan lima indikator keterampilan menjelaskan fenomena secara ilmiah yang telah dijabarkan pada Tabel 2 . Sebanyak 267 butir soal (Tabel 3) PTS dan PAS matapelajaran IPA- Biologi berbentuk pilihan ganda dan essay terkumpul dari enam SMP di Kota Bandung, yakni dari dua sekolah swasta dengan kategori "baik", satu sekolah negeri dan satu sekolah swasta dengan kategori "cukup", serta satu sekolah negeri dan satu sekolah swasta dengan kategori "kurang". Pengkodean sekolah dalam penelitian ini meliputi jenjang sekolah, kategori sekolah, no sekolah dalam kategori, dan status sekolah. Berikut merupakan kode sekolah yang digunakan dalam penelitian dan proporsi jumlah soal dari masing-masing sekolah yang diperoleh pada penelitian, yang disajikan pada Tabel 3 sebagai berikut.

Tabel 3. Kode sekolah dan proporsi jumlah soal dari enam SMP di Kota Bandung

\begin{tabular}{clccccc}
\hline No & Kode Sekolah & Kategori & $\begin{array}{c}\text { Status } \\
\text { Sekolah }\end{array}$ & $\begin{array}{c}\text { Jumlah } \\
\text { Soal PTS }\end{array}$ & $\begin{array}{c}\text { Jumlah } \\
\text { Soal PAS }\end{array}$ & Total \\
\hline 1. & SMPB01Sw & Baik & Swasta & 23 & 30 & 53 \\
\hline 2. & SMPB02Sw & Baik & Swasta & 10 & 14 & 24 \\
\hline 3. & SMPC01Sw & Cukup & Swasta & 20 & 39 & 59 \\
\hline 4. & SMPC02N & Cukup & Negeri & 40 & 16 & 56 \\
\hline 5. & SMPK01N & Kurang & Negeri & 14 & 12 & 26 \\
\hline 6 & SMPK02Sw & Kurang & Swasta & 30 & 19 & 49 \\
\hline \multicolumn{7}{c}{ Total keseluruhan soal } \\
\hline
\end{tabular}

Berdasarkan Gambar 1 tampak bahwa butir soal tentang keterampilan menjelaskan fenomena secara ilmiah dengan menggunakan indikator keterampilan yang mengacu pada OECD (2018), ditemukan bahwa hanya sebagian kecil $(0,74 \%$ dan $1,12 \%)$ atau $(1,86 \%)$ butir soal yang "sesuai" indikator keterampilan menjelaskan fenomena secara ilmiah. Bila ditinjau dari indikator keterampilan menjelaskan fenomena secara ilmiah. Pada butir soal hanya terdapat indikator kemampuan menerapkan pengetahuan ilmiah dengan tepat (MPI01) yang diperoleh dari soal PTS dan PAS dari dua SMP di
Kota Bandung. Butir soal yang memuat tentang indikator menerapkan pengetahuan ilmiah dengan tepat (MPI01) memuat soal dengan gambar/data/fenomena yang dapat diselidiki siswa untuk menjawab pertanyaan yang diajukan. Data/fenomena/gambar tersebut dapat digunakan siswa untuk melakukan penyelidikan dan menutut siswa untuk berpikir kritis terhadap sebuah fenomena/gambar/data yang disajikan pada stem soal tersebut. Berikut merupakan Gambar 1 menyajikan perolehan persentase butir soal "sesuai" indikator keterampilan menjelaskan fenomena secara ilmiah. 


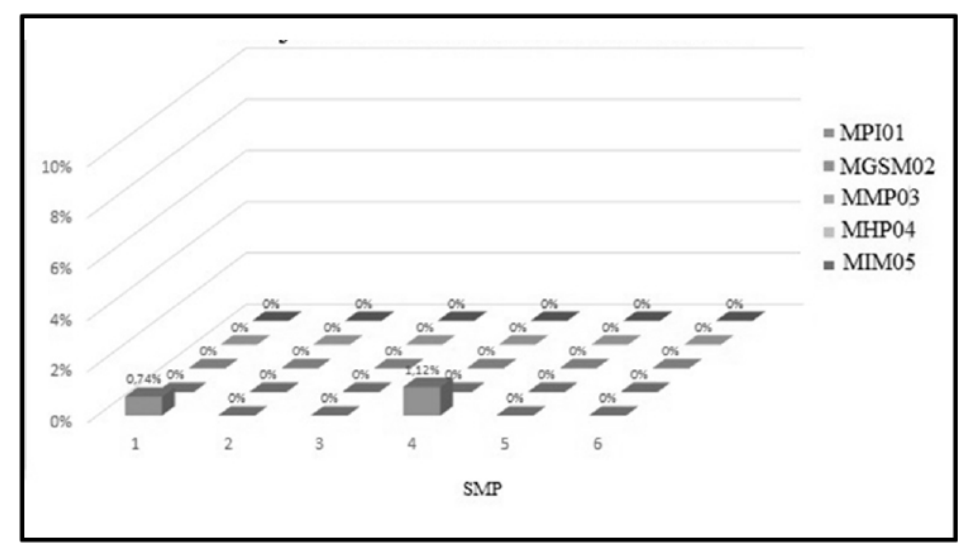

Gambar 1. Keberadaan butir soal "sesuai" keterampilan menjelaskan fenomena secara ilmiah di enam SMP Kota Bandung

Keterangan: 1:SMPB01Sw: SMP kategori "baik 1" dengan status sekolah swasta; 2:SMPB02Sw: SMP kategori "baik 2" dengan status sekolah swasta; 3:SMPC01Sw: SMP kategori "cukup 1" dengan status sekolah swasta; 4:SMPC02N: SMP kategori "cukup 2" dengan status sekolah negeri; 5:SMPK01N: SMP kategori "kurang 1" dengan status sekolah negeri; 6:SMPK02Sw: SMP kategori "kurang 2" dengan status sekolah swasta; MP101: Menerapkan pengetahuan ilmiah dengan tepat; MGSM02: Menggunakan gambaran serta model dengan jelas; MMP03: Menyusun dan memberikan prediksi dengan tepat; MHP04: Mengajukan hipotesis penjelasan; MIM05: Menjelaskan implikasi potensial dari pengetahuan ilmiah untuk masyarakat.

Selain itu, pada Gambar 2 ditemukan pula butir soal dari enam SMP di Kota Bandung yang "mendekati sesuai" dengan indikator keterampilan menjelaskan fenomena secara ilmiah. Butir soal yang dianalisis memuat indikator keterampilan menjelaskan fenomena secara ilmiah pada indikator kemampuan menerapkan pengetahuan ilmiah dengan tepat (MPI01) namun kurang memuat karakteristik prasyarat soal keterampilan menjelaskan fenomena secara ilmiah. Berikut disajikan presentase butir soal "mendekati sesuai" dengan indikator keterampilan menjelaskan fenomena secara ilmiah yang disajikan pada gambar 2.

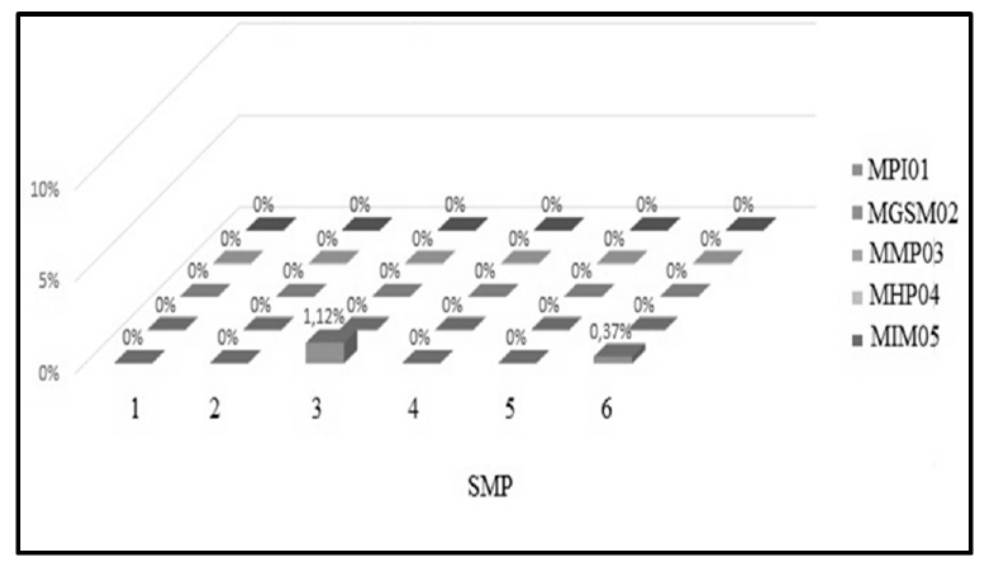

Gambar 2. Keberadaan penggunaan butir soal tes tertulis "mendekati sesuai” keterampilan menjelaskan fenomena secara ilmiah di enam SMP Kota Bandung

Keterangan: 1:SMPB01Sw: SMP kategori "baik 1" dengan status sekolah swasta; 2:SMPB02Sw: SMP kategori "baik 2" dengan status sekolah swasta; 3:SMPC01Sw: SMP kategori "cukup 1" dengan status sekolah swasta; 4:SMPC02N: SMP kategori “cukup 2" dengan status sekolah negeri; 5:SMPK01N: SMP kategori "kurang 1" dengan status sekolah negeri; 6:SMPK02Sw: SMP kategori "kurang 2" dengan status sekolah swasta; MP101: Menerapkan pengetahuan ilmiah dengan tepat; MGSM02: Menggunakan gambaran serta model dengan jelas; MMP03: Menyusun dan memberikan prediksi dengan tepat; MHP04: Mengajukan hipotesis penjelasan; MIM05: Menjelaskan implikasi potensial dari pengetahuan ilmiah untuk masyarakat 
Berdasarkan Gambar 1 dan Gambar 2 diperoleh hanya indikator menerapkan pengetahuan ilmiah dengan tepat (MPI01) yang terdapat pada butir soal yang digunakan oleh guru/sekolah dari enam SMP di Kota Bandung dengan kriteria sekolah baik, cukup dan kurang. Hal tersebut kemungkinan dapat didasari karena tingkat kesukaran indikator keterampilan menjelaskan fenomena secara ilmiah. Pada indikator keterampilan menerapkan pengetahuan ilmiah dengan tepat (MPI01) tuntutan tes tertulis yang disajikan oleh guru yaitu meminta siswa untuk menerapkan pengetahuan konsep dengan menghubungkan informasi yang terdapat pada stem soal untuk menjawabnya. Indikator keterampilan menerapkan pengetahuan ilmiah dengan tepat (MPI01) merupakan bagian dari keterampilan menjelaskan fenomena secara ilmiah, yang merupakan bagian dari literasi sains.

\subsection{Pembahasan}

Rendahnya muatan literasi sains tentang keterampilan menjelaskan fenomena secara ilmiah pada butir soal tes tertulis yang digunakan oleh guru/sekolah kemungkinan besar juga dapat disebabkan karena perbedaan sasaran terhadap kemampuan literasi sains pada pembelajaran yang diterapkan di sekolah (sekalipun sudah menggunakan Kurikulum 2013) dengan sasaran literasi sains dalam PISA tentang keterampilan menjelaskan fenomena secara ilmiah (Diana, 2016). Selain itu pembelajaran IPA di sekolah termasuk asesmennya lebih terbatas pada pengembangan materi/konten IPA, sementara sasaran dalam soal literasi saians PISA lebih pada penerapan cara berpikir ilmiah (reasoning) dikehidupan sehari-hari (Fives et al., 2014; Pranoto, 2013) dan fokus pada aksi pengetahuan praktis serta mengukur kemampuan menggunakan prinsip ilmiah dalam konteks non akademik (Shwartz et al., 2006).

Buku teks yang digunakan oleh guru dan siswa juga mempengaruhi pembelajaran literasi sains di dalam kelas. Buku teks sangat mempengaruhi pola pembelajaran guru dan siswa, sehingga mempengaruhi proses asesmen yang dikembangkan oleh guru. Menurut Penney et al. (2003) mengungkapkan bahwa buku teks pelajaran merupakan faktor penting dalam pengembangan literasi sains dan menyediakan jalan untuk pembelajaran jangka panjang di dalam sains. Menurut hasil penelitian yang dilakukan oleh Wahyu et al., (2016) terhadap muatan buku teks IPA yang digunakan oleh guru dan siswa. Didapati bahwa buku teks yang digunakan guru sebagian besar berisikan muatan pengetahuan sains yang menyajikan fakta, konsep, prinsip, hukum, teori, dan pertanyaan-pertanyaan yang meminta siswa untuk mengingat konsep, pengetahuan ataupun informasi, sedangkan Wahyu et al., (2016) pada muatan kategori interaksi sains, teknologi dan masyarakat sangat rendah yaitu sebesar $4,0 \%$.

Surpless et al. (2014) rendahnya literasi sains dalam pola pembelajaran juga dapat disebabkan karena proses pembelajaran di sekolah (termasuk di Perguruan Tinggi) yang masih menekankan penguasaan konten bukan melalui proses ilmiah. Erwin et al. (2019) juga mengungkapkan bahwa kemampuan literasi sains guru IPA di SMP masih rendah, sehingga dapat mempengaruhi kemampuan guru dalam mengembangkan butir soal literasi sains. Terdapat gap antara pembelajaran sains di sekolah dengan tuntutan literasi sains PISA salah satunya tentang keterampilan menjelaskan fenomena secara ilmiah (Ardianto \& Rubini, 2016), sehingga diperlukan pembenahan dalam pembelajaran sains, misalnya dengan menerapkan pengajaran berbasis literasi sains (Widiyanti et al., 2015). Padahal pengembangan asesmen pembelajaran salah satunya pada butir soal tes tertulis diharapkan menuntut aspek-aspek literasi sains, dengan tidak hanya bermuatan konsep saja (Sariwulan et al., 2015).

Berdasarkan pemaparan di atas, berikut merupakan butir soal dengan kriteria soal "tidak sesuai", dan "mendekati sesuai" sehubungan dengan indikator soal keterampilan menjelaskan fenomena secara ilmiah yang diperoleh dari enam SMP di Kota Bandung sebagai berikut. 
(Tidak sesuai) Berikut ini yang bukan merupakan fungsi hidung dalam proses pernapasan adalah ....

A. Sebagai tempat pertukaran gas oksigen dan gas karbon dioksida

B. Mengatur suhu udara yang masuk ke dalam paru-paru

C. Mengatur kelembapan udara yang masuk ke dalam paru-paru

D. Menyaring partikel debu atau kotoran yang masuk bersama udara

(Tidak sesuai) Kegiatan untuk membersihkan permukaan tanah yang tercemar disebut dengan
A. Bioremediasi
B. Antioksidanisasi
C. Remediasi
D. Gotong royong

(Tidak sesuai) Gerakan tumbuhan yang dipengaruhi oleh rangsang cahaya dinamakan
A. Niktinasti dan gravitropi
B. Fotonasti dan fototropisme
C. Hidronasti dan hidrotropisme
D. Kemonasti dan kemotrospime

(Tidak sesuai) Tumbuhan yang mendominasi bioma taiga adalah
A. Rumput palem
B. Palem
C. Pinus
D. Kaktus

(Tidak sesuai) Bakteri escherichia coliyang membantu proses pencernaan dan pembentukan vitamin $\mathrm{K}$ dalam usus manusia termasuk kingdom ....
A. Monera
B. Fungi
C. Plantae
D. Protista

(Tidak sesuai) Zat makanan yang berfungsi sebagai sumber energi adalah ....
A. protein dan vitamin
B. lemak dan protein
C. karbohidrat dan lemak
D. vitamin dan mineral

(Mendekati sesuai) Mengapa saat kedinginan kamu cepat merasa lapar? Jelaskan!

(Mendekati sesuai) Orang yang bergolongan darah A tidak mungkin mendonorkan darahnya kepada orang yang bergolongan darah B karena akan terjadi penggumpalan darah. Hal ini terjadi karena ... .

A. antigen B akan bertemu dengan antibodi $\alpha$

B. antibodi $\beta$ akan bertemu dengan antigen B

C. antigen A akan bertemu dengan antibodi $\beta$

D. antibodi $\alpha$ akan bertemu dengan antibodi $\beta$

\section{KESIMPULAN}

Berdasarkan hasil temuan, pengolahan data, dan pembahasan yang diperoleh dari penelitian yang telah dilakukan, didapatkan gambaran terhadap butir soal tentang keterampilan menjelaskan fenomena secara ilmiah pada matapelajaran IPA-Biologi SMP. Berdasarkan hasil studi yang telah dilakukan hanya sebagian kecil butir soal tes tertulis yang memuat tentang keterampilan menjelaskan fenomena secara ilmiah pada matapelajaran IPABiologi di SMP yang digunakan guru/ sekolah pada soal PTS dan PAS. Penelitian ini dapat memberikan umpan balik kepada guru, sekolah, peneliti, dan dinas pendidikan mengenai butir soal tes tertulis yang digunakan guru/sekolah tentang keterampilan menjelaskan fenomena secara ilmiah pada matapelajaran IPABiologi di SMP pada soal PTS dan PAS, sehingga diharapkan guru dapat mendesain suatu model tes tertulis yang memuat butir soal tentang keterampilan menjelaskan fenomena secar ilmiah. Butir soal tersebut dapat direkomendasikan untuk mengases keterampilan siswa pada matapelajaran IPA-Biologi SMP tentang keterampilan menjelaskan fenomena secara ilmiah yang sesuai dengan materi pada kurikulum IPABiologi. 


\section{DAFTAR PUSTAKA}

Amrianto. (2017). Analisis Soal Ujian Tengah Semester II Mata Pelajaran IPA Kelas VIII SMP Pembangunan Laboratorium Universitas Negeri Padang Dan SMP Pertiwi Siteba Padang Tahun Pelajaran 2015/2016 [Universitas Negeri Padang]. https://doi.org/10.31227/osf.io/c9hg8.

Ardianto, D., \& Rubini, B. (2016). Comparison of students' scientific literacy in integrated science learning through model of guided discovery and problem based learning. Jurnal Pendidikan IPA Indonesia, 5(1), 31-37. https://doi.org/10.15294/jpii.v5i1.5786.

Ariyana, L. T. (2011). Analisis Butir Soal Ulangan Akhir Semester Gasal IPA Kelas IX SMP di Kabupaten Grobogan [Universitas Negeri Semarang]. In Jurnal Materi dan Pembelajaran Fisika (Vol. 10, Issue 1). https://jurnal.uns.ac.id/jmpf/article/view/42084.

Ates, S., \& Cataloglu, E. (2007). The effects of students' cognitive styles on conceptual understandings and problem-solving skills in introductory mechanics. Research in Science and Technological Education, 25(2), 167-178. https://doi.org/10.1080/02635140701250618.

Australian Learning \& Teaching Council. (n.d.). Assessment 2020 Seven propositions for assessment reform in higher education Preamble.

Ayuningtyas, R. S. (2016). Abstrak Profil Kompetensi Literasi Sains Siswa Berdasarkan Programme For International Student Assesment (PISA) Pada Konten Biologi (Kuasi Deskriptif Siswa Kelas IX SMP seKecamatan Kedaton di Bandar Lampung). Universitas Lampung.

Damayanti, A., Parakkasi, P., \& Sabilu, M. (2016). Analisis Kualitatif Tes Ulangan Semester Genap Mata Pelajaran IPA Terpadu Materi Biologi SMP Negeri 4 Tomia Kecamatan Tomia Kabupaten Wakatobi Tahun Pelajaran 2014/2015. AMPIBI: Jurnal Alumni Pendidikan Biologi, 1(1), 12-23. http://ojs.uho.ac.id/index.php/ ampibi/article/view/5019.

DIANA, S. (2016). Pengaruh penerapan strategi peer assisted learning (PAL) terhadap kemampuan literasi sains mahasiswa dalam perkuliahan morfologi tumbuhan. Jurnal Pengajaran MIPA, 21(1), 82-91.

Elvadola, C. (2016). The Programme for International Student Assesment (PISA) PADA KONTEN BIOLOGI (Kuasi Deskriptif Siswa Kelas IX SMP se-Kecamatan Kemiling di Bandar Lampung). Universitas Negeri Lampung.

Firman, H. (2007). Laporan Analisis Literasi Sains Berdasarkan Hasil PISA Nasional Tahun 2006.

FiveS, H., Huebner, W., Birnbaum, A. S., \& Nicolich, M. (2014). Developing a Measure of Scientific Literacy for Middle School Students. Science Education, 98(4), 549-580. https://doi.org/10.1002/sce.21115.

Goh, D. (2016). Expanded Understandings of the Connective Approach in Helping Students Construct Scientific Explanations. SAGE Open, 6(3). https://doi.org/10.1177/2158244016663608.

Hartika, D. (2016). Profil Kompetensi Literasi Sains Siswa Berdasarkan The Programme For International Student Assesment (PISA) Pada Konten Biologi (Kuasi Deskriptif Siswa Kelas IX SMP se-Kecamatan Teluk Betung Utaradi Bandar Lampung). Fakultas Keguruan Dan Ilmu Pengetahuan.

Herlant, Y., \& Nopithalia. (2005). Meneropong Kualitas Soal Tes Buatan Guru Biologi MTs Negeri Se-Jakarta Selatan. http:/www.tempointeraktif.com/hg/nasional/2005/12/12/brk,20051212-

Johari, A. (2018). Analisis Kualitas Soal-Soal Try Out Ujian Nasional Mata Pelajaran IPA SMP Di Kabupaten Boyolali Tahun Pelajaran 2017/2018 [Universitas Muhammadiyah Surakarta]. http://eprints.ums. ac.id/66318/3/NASKAH PUBLIKASI PRINT.pdf.

Kemampuan, A., Sains, L., Guru, T., Pengetahuan, I., Smp, A., Di, N., Lainea, K., Andoolo, D., Konawe, K., Erwin, S., Tahang, L., \& Galib, L. M. (2019). Analisis Kemampuan Literasi Sains dan Teknologi Guru Ilmu Pengetahuan Alam SMP Negeri di Kecamatan Lainea dan Andoolo Kabupaten Konawe Selatan. JIPFi Jurnal Penelitian Pendidikan Fisika, 4(4), 13-22. https://doi.org/10.36709/JIPFI.V4I4.9745.

Kumano, Y. (2001). Authentic Assessment and Portfolio Assessment-Its Theory and Practice. Shizuoka University.

Lawson, A. E., Banks, D. L., \& Logvin, M. (2007). Self-efficacy, reasoning ability, and achievement in college biology. Journal of Research in Science Teaching, 44(5), 706-724. https://doi.org/10.1002/tea.20172.

Lawson, A. E., Clark, B., Cramer-Meldrum, E., Falconer, K. A., Sequist, J. M., \& Kwon, Y. J. (2000). Development of scientific reasoning in college biology: Do two levels of general hypothesis-testing skills exist? Journal of Research in Science Teaching, 37(1), 81-101. https://doi.org/10.1002/(SICI)10982736(200001)37:1<81::AID-TEA6>3.0.CO;2-I.

Narut, Y. F., \& Supardi, K. (2019). Literasi Sains Peserta Didik Dalam Pembelajaran IPA di Indonesia. JIPD (Jurnal Inovasi Pendidikan Dasar), 3(1). https://ejournal.stkipsantupaulus.ac.id/index.php/jipd/article/ view/414. 
Novika, A. (2016). Abstrak Profil Kompetensi Literasi Sains Siswa Berdasarkan The Programme For International Student Assessment (PISA) Pada Konten Biologi (Kuasi Deskriptif Siswa Kelas IX SMP Se-Kecamatan Tanjungkarang Barat di Bandar Lampung). Universitas Negeri Lampung.

OECD. (2017). PISA for Development Assessment and Analytical Framework . www.oecd.org/about/publishing/ corrigenda.htm.

OECD. (2018). PISA 2015: Result in Focus.

Penney, K., Norris, S. P., Phillips, L. M., \& Clark, G. (2003). The anatomy of junior high school science textbooks: An analysis of textual characteristics and a comparison to media reports of science. Canadian Journal of Science, Mathematics and Technology Education, 3(4), 415-436. https://doi. org/10.1080/14926150309556580.

Pranoto, I. (2013, February). Guru Merdeka. Kompas, 7.

Pratiwi, I. (2019a). Efek Program Pisa Terhadap Kurikulum Di Indonesia. Jurnal Pendidikan Dan Kebudayaan, 4(1), 71. https://doi.org/10.24832/jpnk.v4i1.1157.

Pratiwi, I. (2019b). Efek Program Pisa Terhadap Kurikulum Di Indonesia. Jurnal Pendidikan Dan Kebudayaan, 4(1), 60. https://doi.org/10.24832/jpnk.v4i1.1157.

Rachmatullah, A. (2015). Profil Capaian Literasi Sains Siswa Smp Di Kabupaten Sumedang Dengan Menggunakan Scientific Literacy Assessments (SLA). Universitas Pendidikan Indonesia.

Rustaman, N. Y. (2017). Mewujudkan Sistem Pembelajaran Sains/Biologi Berorientasi Pengembangan Literasi Peserta Didik. Prosiding Seminar Nasional Iii Tahun 2017 "Biologi, Pembelajaran, Dan Lingkungan Hidup Perspektif Interdisipliner” Diselenggarakan Oleh Prodi Pendidikan Biologi-FKIP Bekerjasama Dengan Pusat Studi Lingkungan Dan Kependudukan (PSLK), O(0), 1-8. http://research-report.umm.ac.id/ index.php/.

Salpeter, J. (2013, October 15). 21 st Century Skills: Will Our Students Be Prepared? . Tech \& Learning. https:// www.techlearning.com/news/21st-century-skills-will-our-students-be-prepared.

SAMUDAR, N. (2019). Kualitas Soal Ujian Sekolah Berstandar Nasional IPA SMP Di Kabupaten Luwu Utara. Universitas Negeri Makassar.

Sandoval, W. A., \& Millwood, K. A. (2005). The quality of students' use of evidence in written scientific explanations. In Cognition and Instruction (Vol. 23, Issue 1, pp. 23-55). Routledge. https://doi.org/10.1207/ s1532690xci2301_2.

Sariwulan, D., Rachmatulloh, A., \& Rahmawati, E. S. (2015). Profil Kemampuan Literasi Sains Siswa SMA Berdasarkan Instrumen Scientific Literacy Assesments (SLA). Seminar Nasional XII Pendidikan Biologi, 285-291.

Schleicher, A. (2017). Seeing education through the prism of PISA. European Journal of Education, 52(2), 124130. https://doi.org/10.1111/ejed.12209.

Septiana, N. (2016). Analisis Butir Soal Ulangan Akhir Semester (UAS) Biologi Tahun Pelajaran 2015/2016 Kelas X Dan XI Pada Man Sampit. Edu Sains: Jurnal Pendidikan Sains Dan Matematika, 4(2), 60-71. https:// doi.org/10.23971/EDS.V4I2.514.

Shwartz, Y., Ben-Zvi, R., \& Hofstein, A. (2006). The use of scientific literacy taxonomy for assessing the development of chemical literacy among high-school students. Chemistry Education Research and Practice, 7(4), 203-225. https://doi.org/10.1039/B6RP90011A.

Stiggins, R. J. (1994). Student-Centered Classroom Assessment A Set of Guiding Principles. Macmillan College Publishing Company.

Wahyu, E. R., \& Fathurohman, A. (2016). Analisis Buku Siswa Mata Pelajaran IPA Kelas VIII SMP/MTs Berdasarkan Kategori Literasi Sains. Jurnal Inovasi Dan Pembelajaran Fisika, 3(2), 10-19. https://doi. org/10.36706/JIPF.V3I2.3837.

Supeno, Kurnianingrum, A. M., \& Cahyani, M. U. (2017). Kemampuan Penalaran Berbasis Bukti Dalam Pembelajaran Fisika. Jurnal Pembelajaran Dan Pendidikan Sains, 2(1), 64-78.

Suprayitno, T. (2019). Pendidikan di Indonesia: belajar dari hasil PISA 2018. Badan Penelitian dan Pengembangan.

Surpless, B., Bushey, M., \& Halx, M. (2014). Developing scientific literacy in introductory laboratory courses: A model for course design and assessment. Journal of Geoscience Education, 62(2), 244-263. https://doi. org/10.5408/13-073.1.

Tiararahmadani, A. (2018). Kemampuan Guru IPA Dalam Membuat Soal Ulangan Harian Kelas VIII di SMP Negeri Kabupaten Sukoharjo Tahun Ajaran 2016/2017 Berdasarkan Ranah Kognitif Taksonomi Bloom. 
Universitas Muhammadiyah Surakarta.

Waldow, F. (2009). What PISA did and did not do: Germany after the "PISA-shock." European Educational Research Journal, 8(3), 476-483. https://doi.org/10.2304/eerj.2009.8.3.476.

Wang, T. H. (2014). Implementation of Web-based argumentation in facilitating elementary school students to learn environmental issues. Journal of Computer Assisted Learning, 30(5), 479-496. https://doi.org/10.1111/ jcal.12061.

Widiyanti, F., Indriyanti, D. R., \& Ngabekti, S. (2015). The effectiveness of the application of scientific literacybased natural science teaching set toward the students' learning activities and outcomes on the topic of the interaction of living organism and environment. Jurnal Pendidikan IPA Indonesia, 4(1), 20-24. https:// doi.org/10.15294/jpii.v4i1.3496.

Wijaya, E. Y., Sudjimat, D. A., \& Nyoto, A. (2016). Transformasi Pendidikan Abad 21 Sebagai Tuntutan Pengembangan Sumber Daya Manusia Di Era Global. Prosiding Seminar Nasional Pendidikan Matematika 2016, 1, 263-278.

Wulan, A. R., Suwandi, T., Utari, S., Purwati, R., \& Liestari, S. R. (2019). Pengembangan Instrumen untuk Mengukur Cognitive Skills Kompetensi Abad 21- Keterampilan Memverifikasi Kesahihan Penelitian pada Pelajaran IPA. .

Yamamoto, K. (2009). A New Biology for the 21 st Century. https://doi.org/10.17226/12764. 